\title{
The African weaver ant has no negative impact on spiders in mango orchards of Senegal
}

\author{
Thibault Nève de Mévergnies $^{1,2}$ ( $\mid$ Anaïs Chailleux ${ }^{1,3,4} \mid$ Claire Detrain $^{2}$ \\ ${ }^{1}$ Biopass, Cirad-ISRA-UCAD-IRD, Dakar, Senegal \\ ${ }^{2}$ Unit of Social Ecology, Université Libre de Bruxelles, Brussels, Belgium \\ ${ }^{3}$ Cirad, UPR HortSys, Dakar, Senegal \\ ${ }^{4}$ Cirad, Univ. Montpellier, Montpellier, France \\ Correspondence \\ Thibault Nève de Mévergnies, Biopass, Cirad-ISRA-UCAD-IRD, Dakar, Senegal. \\ Email: tneve@hotmail.fr \\ Funding information \\ Académie de recherche et d'enseignement supérieur; TROPIMUNDO
}

\section{1 | INTRODUCTION}

Sustainable pest-control strategies aim to limit the abundance of pests through, for example, maintenance of their predators in the system. The use of multiple generalist predators can enhance pest control through additive or synergistic effects due to their complementarity (Letourneau et al., 2009). However, their presence can also lead to drawbacks such as off-target or intraguild predation (Rosenheim et al., 1995).

In many African agroecosystems, top predator effects on sympatric communities still await to be disentangled and effective sustainable control of invasive pests is lacking (de Bon et al., 2014; Grzywacz et al., 2014). In Senegal, mango production is devastated by an invasive pest, the oriental fruit fly Bactrocera dorsalis (Hendel) (Diptera: Tephritidae), which is responsible for important economic losses (Vayssières et al., 2014). A solution has been implemented through the presence of the arboreal weaver ant Oecophylla longinoda Latreille (Hymenoptera: Formicidae) in large parts of SubSaharan Africa, including Senegal. Indeed, this generalist predator exerts aggressive control over its territories, which include multiple host trees such as mango and citrus, reducing the fly pest densities through predation and repellence (Diamé et al., 2015; Vayssières et al., 2016; Way, 1954). As dominant generalist predators, weaver ants are however responsible for negative interactions towards beneficial organisms such as some pollinators (Tsuji et al., 2004), parasitoids (Migani et al., 2017; Tanga et al., 2015) and a lynx spider (Oxyopes sp.) (Peng \& Christian, 2013). While the positive impact of weaver ants on fruit yields suggests that the benefits they provide to crops usually outweigh the costs (Diamé et al., 2017; Thurman et al.,
2019), there is still a lack of knowledge about their interactions with other organisms within their trophic guild.

We thus investigated the interactions between O. longinoda and the Araneae community in Senegalese mango orchards. Indeed, spiders are abundant generalist predators (Nyffeler \& Birkhofer, 2017) that naturally regulate arthropod pest populations and as such have been effectively used as control agents in many agroecosystems worldwide (Rajeswaran et al., 2005; Riechert \& Lockley, 1984). We hypothesised that certain spider families suffer from competition and/or intraguild predation from the weaver ants in their overlapping territories. In particular, we expected that actively hunting spiders such as jumping spiders (Salticidae), or sac spiders (Clubionidae) would see their population numbers decrease as they potentially share the same hunting grounds and prey as the weaver ants.

\section{2 | MATERIALS AND METHODS}

\section{1 | Study site and spider sampling}

The Niayes region of Senegal is under Sahelian climate with unimodal rainfall (250-350 mm per year) from July to September. We sampled 10 mango orchards in this zone with similar characteristics (Appendix 1) in February 2020, during the dry season when trees are flowering. In each, we randomly selected three non-contiguous mango trees bearing distinct $O$. longinoda ant colonies, and three trees without ants. We evaluated the density of ants on each tree by counting the number of ants on trails on a $1 \mathrm{~m}$ portion of the main branches, following Pinkalski et al. (2015). We made sure that the 


\begin{tabular}{|llllcll}
\hline Ants & Habitat & N & S & Median s (Q1-Q3) & D & H \\
\hline Yes & Canopy & 297 & 53 & $12.5(11.00-15.75)$ & 0.928 & 3.170 \\
& Ground & 153 & 55 & $8.5(8.00-12.75)$ & 0.965 & 3.672 \\
& Total & 450 & 95 & $11.5(8.75-14.2)$ & 0.959 & 3.842 \\
\multirow{2}{*}{ No } & Canopy & 280 & 51 & $12.5(12.00-15.50)$ & 0.950 & 3.358 \\
& Ground & 131 & 52 & $7.0(5.25-9.50)$ & 0.941 & 3.443 \\
& Total & 411 & 99 & $11.5(6.75-14)$ & 0.970 & 3.984 \\
\hline
\end{tabular}

TABLE 1 Diversity indices for the spider communities depending on the habitat and the presence of the weaver ant

Note: " $N$ " represents the total abundance of sampled spiders. " $\mathrm{S}$ " is the total morphospecies richness for each habitat when grouped for all sites. "Median s" is the median number of spider morphospecies per site with first (Q1) and third (Q3) quartiles. "D" is the GiniSimpson index and " $\mathrm{H}$ " is the Shannon-Wiener index for the overall sampled spider communities.

(a) Canopy

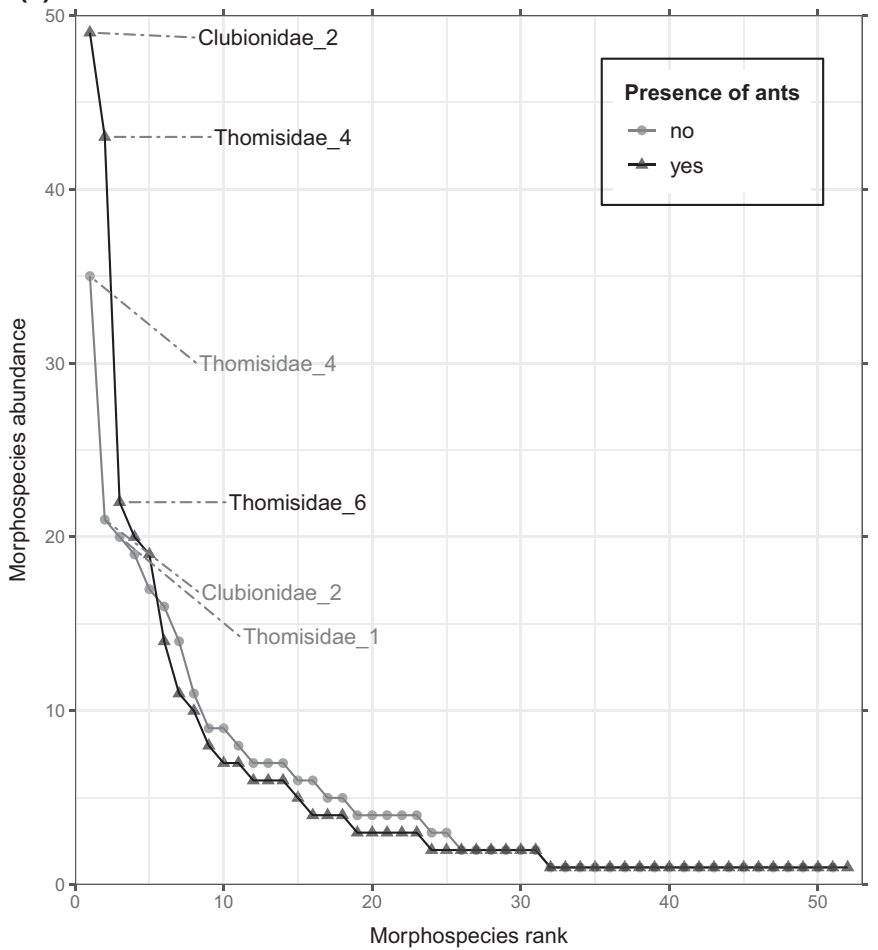

Rank-abundance curves of the spider morphospecies depending on the presence of ants

(b) Ground

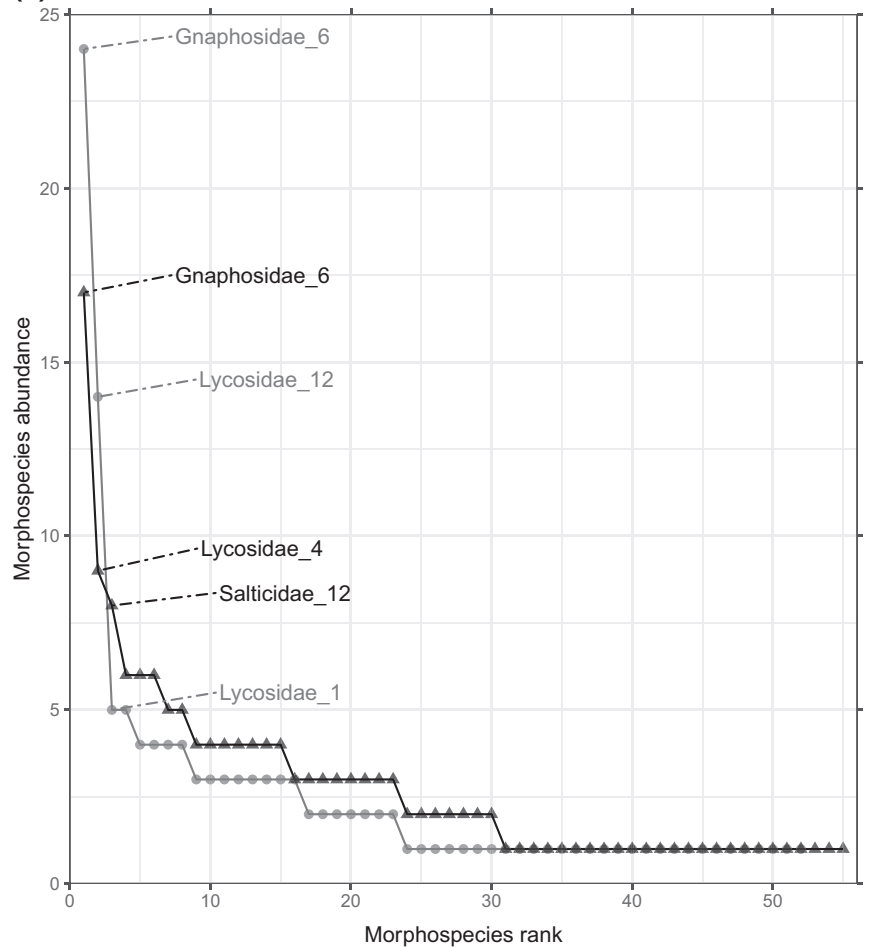

FIGURE 1 Rank-abundance curve (Whittaker plot) ranking the sampled spider morphospecies S in the canopy (a) or on the ground (b) by their abundance depending on the presence (black triangles) or absence (grey circles) of weaver ants

ants belonged to different colonies by assessing the characteristic aggressive behaviour they show towards alien conspecifics.

Per tree, three randomly chosen branches of similar volume, bearing foliage and flowers were beaten five times with a standardised stick over a hand-held $1 \mathrm{~m}^{2}$ catching sheet. Spiders were caught on the sheet using a mouth aspirator and subsequently killed in $70 \%$ alcohol for further identification. Two pitfall traps ( $\approx 500 \mathrm{ml}$ ) were randomly placed under the canopy of each of the selected trees to sample the epigeic spider community. These were filled with water, $30 \%$ ethylene glycol and a drop of detergent to lower surface tension (Schmidt et al., 2006), then left on site for $72 \mathrm{~h}$. Traps were emptied in the field through a sieve ( $2 \mathrm{~mm}$ mesh) to discard soil particles. All spiders were collected and placed in a $70 \%$ ethanol solution, and then brought to the laboratory for identification. Due to the lack of literature about Senegalese spiders, specimens were identified to family level and placed in morphospecies categories based on keys from Jocqué and Dippenaar-Schoeman (2007).

\section{2 | Statistical analysis}

We discarded families with a total sum of individuals per habitat (arboreal or epigeic) of less than six individuals. In addition to the morphospecies richness $(S)$ and the abundance of spiders per family and morphospecies, we calculated two standard diversity indices to evaluate the impact of the presence of ants in each orchard: first, 
the GiniSimpson (D) index that quantifies the probability that two individuals taken randomly in a sample belong to two different species (the higher the $\mathrm{D}$ value the more diverse the community), and second, the Shannon index $(\mathrm{H})$ that quantifies the equitability of the distributions of the sampled morphospecies (the higher $\mathrm{H}$ the more uniform the distribution of relative abundance of morphospecies). To compare these diversity indices grouped per orchard and per habitat depending on the presence of ants, we used non-parametric Wilcoxon rank-sum tests due to non-Gaussian data distribution. Generalised linear mixed models with a Poisson distribution and a log link were implemented to investigate whether the presence of weaver ants (as a fixed factor) influenced the total abundance of the spiders. Then, we carried out permutational multivariate analyses of variances (PERMANOVA) to detect possible effects of weaver ants on the composition of spiders when being considered at the family level. These PERMANOVA analyses were made separately for the canopy and for the ground communities of spiders. Finally, we generated GLMMs to further study the impact of the weaver ant on the abundances of certain spider families or morphospecies of potential interest for their role in biological control. The variable orchard was set as a blocking random factor in all the models. For the spider abundances at family and morphospecies level, we presented results only when a significant difference was detected linked to the presence of weaver ants. All analyses were conducted in R version 4.0.3 ( $R$ Core Team, 2020) using the RStudio interface (RStudio Team, 2020) and the packages ggplot2 (Wickham, 2016), Ime4 (Bates et al., 2015), BiodiversityR (Kindt \& Coe, 2005) and vegan (Oksanen et al., 2019). All results are statistically significant at a $95 \%$ confidence level (alpha $=0.05)$

\section{3 | RESULTS}

All sampled trees bearing ants $(n=30)$ were colonised with an average of 6254 ( \pm 6237 SD) major workers per $\mathrm{m}^{3}$ of canopy. We sampled 577 spider individuals from the mango canopies, and 284 in the pitfalls, to a total of 861 individuals. The spiders belonged to 133 morphospecies representing 17 families. Ninety-five different morphospecies were found in areas where weaver ants were present and 99 in areas where they were absent (Table 1). The most represented families were the jumping spiders Salticidae (25 morphospecies out of 114 sampled individuals). These included Myrmarachne spp. ant mimics. This was followed by the crab spiders Thomisidae (22 morphospecies out of 224 sampled individuals) and the orb weavers Araneidae (19 morphospecies out of 133 sampled individuals) (Appendix 2).

The rank-abundance curves showed no difference linked to the presence of weaver ants (Figure 1a,b). Two morphospecies (Thomisidae_4 and Clubionidae_2) were dominant in the canopy regardless of ant presence (Figure 1b). On the ground, one morphospecies of Gnaphosidae followed by another Lycosidae morphospecies were dominant both in the presence and absence of the weaver ant (Figure 1).
The presence of weaver ants had no significant impact on the total abundance of spiders that were collected per mango tree. This was true in the canopy and on the ground (Table 1. GLMM, $p$ values $>$.05). The diversity indices of the spider community showed no significant differences between orchards relating to the presence of ants, neither in the canopy nor on the ground (Table 1. $n=10$; Wilcoxon, $p$-values $>$.05). At the family level, the composition of the spider communities was not impacted by the presence of the weaver ant whether in the canopy (PERMANOVA, $\mathrm{F}=0.641, p$-value $>.05$ ) nor on the ground (PERMANOVA, $\mathrm{F}=1.086, p$-value $>$.05).

A closer examination of the ants' impact on each family of spiders revealed an abundance of clubionids in the canopy that was significantly higher when weaver ants were present (Figure 2a GLMM, $\chi^{2}=8.69, p$-value $=.003$ ). Similar results were found on the ground (Figure $2 \mathrm{~b}$ GLMM, $\chi^{2}=4.32, p$-value $=.038$ ). Ants had no significant impact on the abundances of the other families, whether in the canopy or on the ground (Figure 2 GLMM, $p$-values > .05).

When considering each morphospecies in the tree canopy, the presence of weaver ants led to a significant increase in the abundance of one morphospecies of araneid (Araneidae_7) (Figure 3a GLMM, $\chi^{2}=4.32, p$-value $<.001$ ) and of one clubionid (Clubionidae_2) (Figure 3b GLMM, $\chi^{2}=10.8, p$-value <.001). On the ground, there was a significant decrease in the abundance of a Lycosidae (Lycosidae_12) when in the presence of the weaver ant (Figure 3c GLMM, $\chi^{2}=5.86, p$-value $=.015$ ). For the other morphospecies, no significant differences in their abundances were detected relating to the presence or absence of the weaver ant (GLMM, $p$-values > .05).

\section{4 | DISCUSSION}

We expected a general decline of sympatric spiders due to resource competition (Vayssières et al., 2015) and intraguild predation (Rosenheim et al., 1995) from the weaver ants, since they are highly aggressive, territorial and able to hunt prey of a similar size range as the spiders' ones (Hölldobler, 1979; Hölldobler \& Wilson, 1990; Wojtusiak et al., 1995). Furthermore, the occurrences of top predators similar to the weaver ants who affect the global composition of a community are commonly reported, for instance with the fire ant (Porter \& Savignano, 1990) or with carpenter ants (Mody \& Linsenmair, 2004). However, in mango orchards of Senegal, our preliminary study reveals that weaver ants do not deter spiders whose total abundance remains unaltered by their presence. Neither had weaver ants any impact on the global composition of the spider families whether in the canopy or on the ground. When considering separately each spider family and morphospecies, we found no negative impact on their abundances linked to the presence of the weaver ant, apart for a small lycosid on the ground. More surprisingly, the presence of the ant in tree canopies even resulted in an increase in the abundance of araneid, clubionid and salticid spiders, though not significant for the latter. A similar result, at a wider arthropod community scale, was found in Australia with their sister 

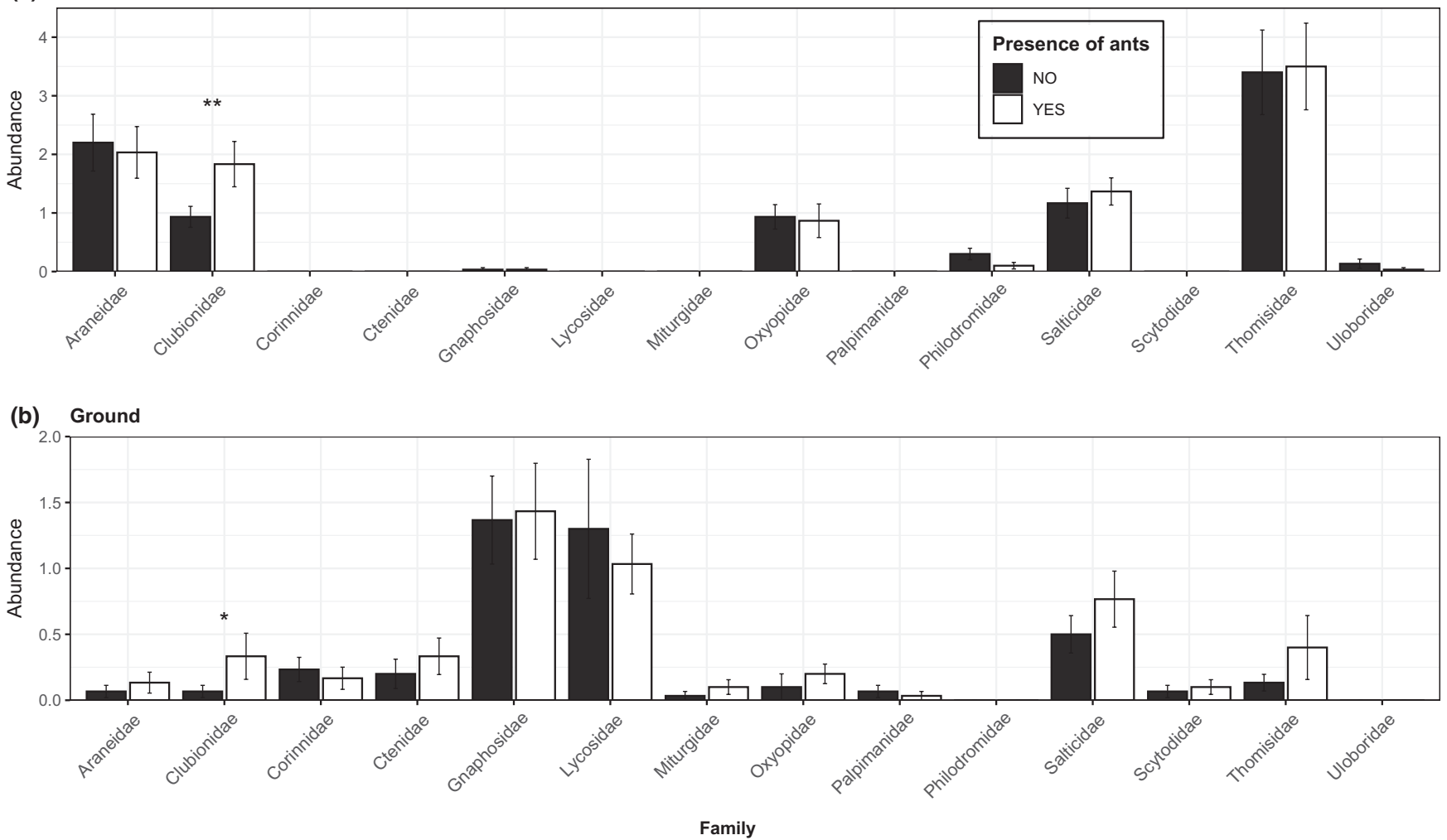

FIGURE 2 Abundance per family of spiders in each canopy (a) or ground (b) sample depending on the presence (white bars) or absence (black bars) of the weaver ant. Values and bars represent mean abundances per sample for each spider family. Error bars represent standard error SE. $n=30$ observations per group. The asterisk indicates significant differences between the abundances of spider families when in the presence or absence of the weaver ant after a GLMM. $p$-value $<.001={ }^{* *}, p$-value $<.05={ }^{*}$

species Oecophylla smaragdina (Fabricius) (Peng \& Christian, 2013). Likewise, in coffee agroecosystems, abundance and diversity of spiders were higher when the ant Azteca instabilis (F. Smith) was present (Marín \& Perfecto, 2013). The reasons behind this neutral to positive impact are probably multifactorial.

First, spiders can evade ant predation due to their multiple escape strategies (Cloudsley-Thompson, 1995). For instance, araneids add alkaloids in their silk, deterring ants from foraging on their webs (Zhang et al., 2012). Different day-night cycles of activities, such as in the nocturnal clubionid spiders, reduce the probability of agonistic encounters with the mainly diurnal weaver ant (Dejean, 1990). In contrast, salticids possess efficient vision-based detection allowing early flight when in danger (Stankowich, 2009).

Second, competitive exploitation is probably limited due to resource partitioning between ants and spiders (Roughgarden, 1976). During the dry season, weaver ants essentially feed on honeydew produced by their hemipteran trophobionts (Vayssières et al., 2015), a resource that is usually of no interest to the spiders. Furthermore, ants cannot catch flying insects such as adult Diptera which are the main prey of many spiders such as web weavers or active hunters on the foliage (Michalko \& Pekár, 2016).

Noticeably, some spiders can directly benefit from the presence of the ants through myrmecophagy (Cushing, 2012). This is the case for certain Myrmarchne spp. (see Figure 3d) that can show specific hunting strategies towards Formicidae and that may behave as inquiline species, feeding on ant larvae inside their nests (Edmunds, 1978; Wanless, 1978). These salticids can also indirectly benefit from occurring in sympatry with the weaver ant, as they appear to be Batesian mimics and hence supposedly gain protection from predators in their vicinity (Collart, 1941; Wanless, 1978).

One should also consider possible indirect benefits for spiders derived from the weaver ant's mutualism with their hemipteran trophobionts (Way, 1963). Indeed, homopterans attract honeydewfeeding insects (Hung et al., 2015; Johnson \& Stafford, 1985), thereby increasing prey abundance, ultimately attracting and favouring entomophagous predators including spiders (Harwood et al., 2003; Wise, 1993). Occasionally, the ant-mimicking Myrmarchne may even feed directly on honeydew, a diet perhaps not limited to this species (Nyffeler et al., 2016; Wanless, 1978).

Lastly, ants are important ecosystem engineers, generating new habitats that can host other organisms (Sanders \& van Veen, 2011). Abandoned woven leaf nests of $O$. longinoda may become refuges to certain spiders, such as some salticids and clubionids (Nève de Mévergnies, pers. obs., February 15 2020).

In conclusion, our study shows that the presence of $\mathrm{O}$. longinoda in mango tree canopies has no negative, but rather a positive impact on the arboreal spider community. Diversity of spider 


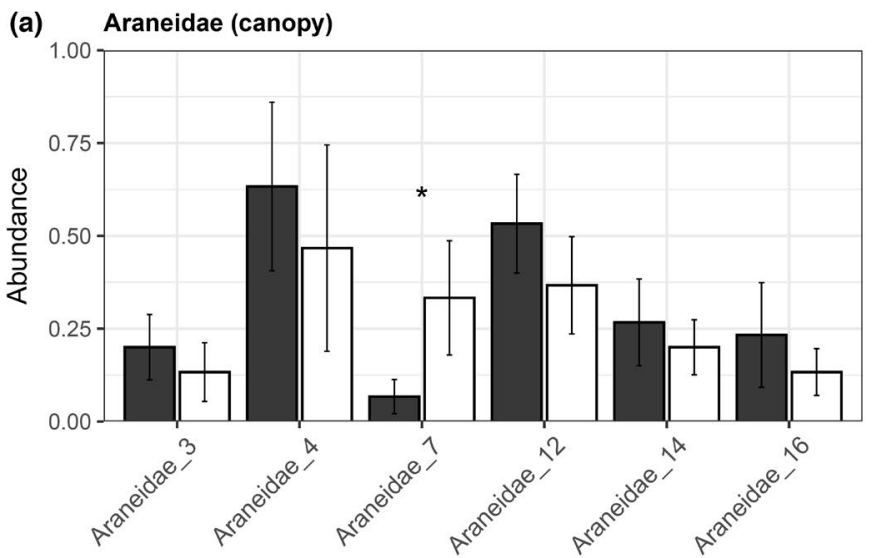

(b) Clubionidae (canopy)

(c) Lycosidae (ground)
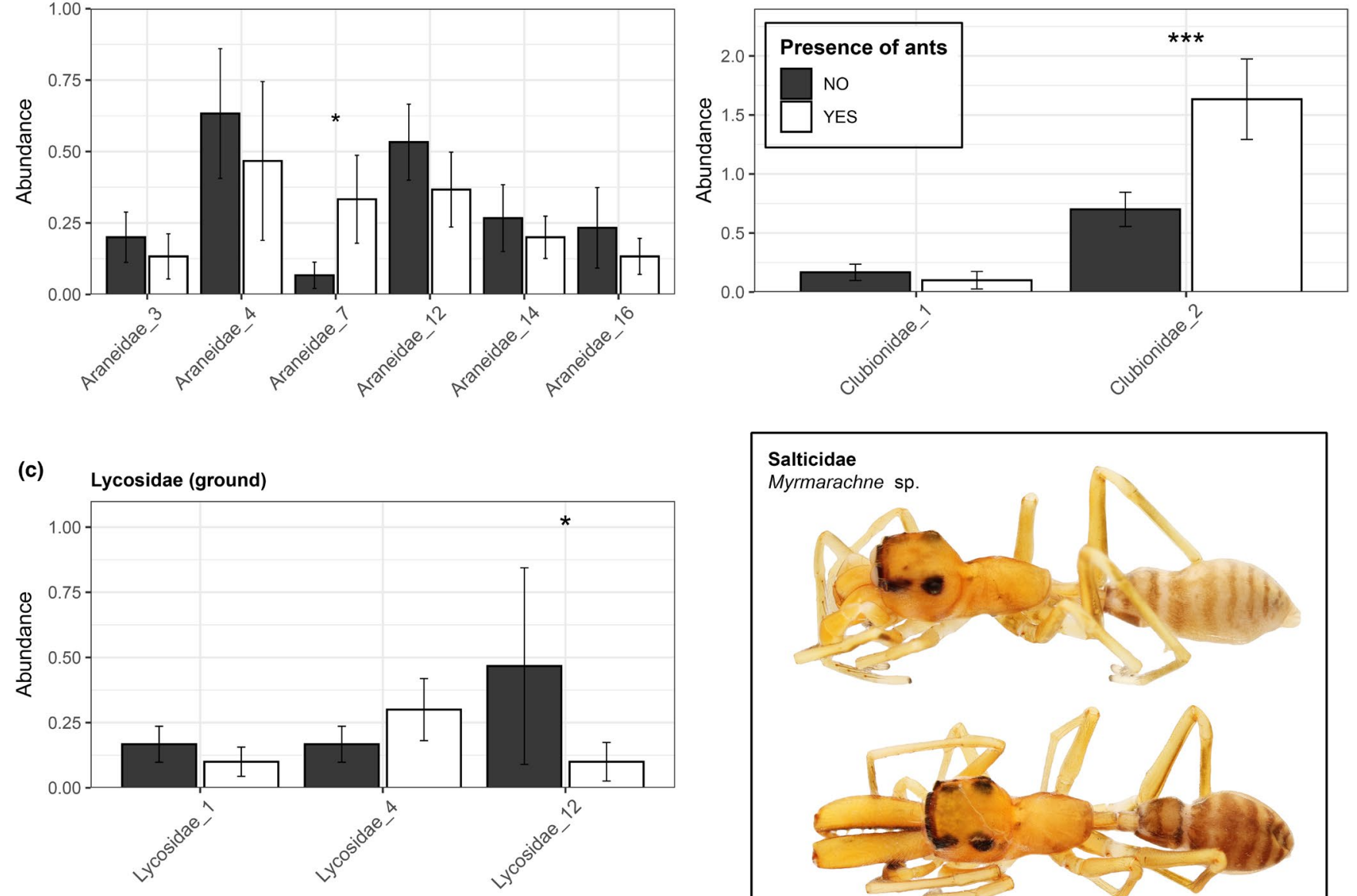

Morphospecies

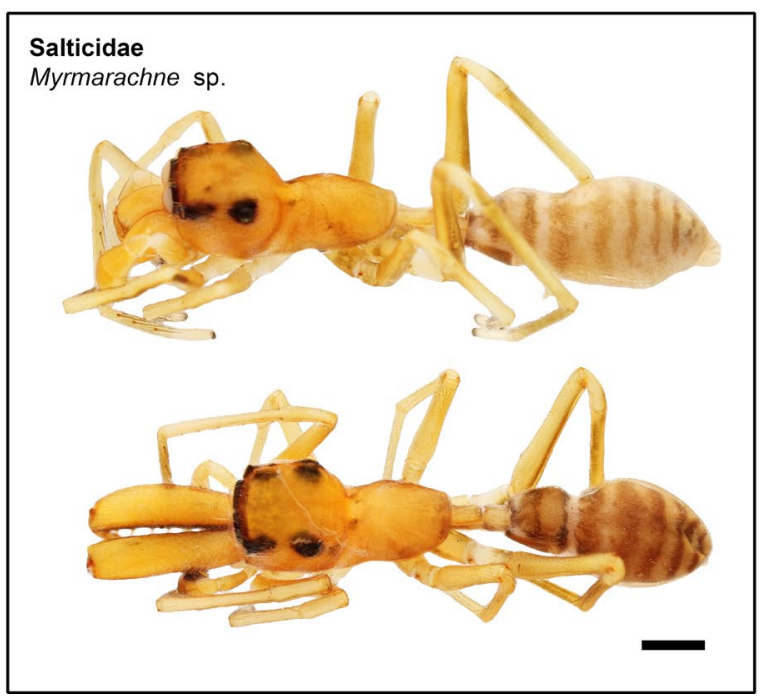

FIGURE 3 Abundance per morphospecies of (a) Araneidae, (b) Clubionidae and (c) Lycosidae in the canopy (a and b) or on the ground (c) depending on the presence (white bars) or absence (black bars) of the weaver ant. Values and bars represent mean abundances per sample for each spider morphospecies. Error bars represent standard error SE. Only morphospecies with a total abundance of $\mathrm{N}>5$ were retained. $n=30$ observations per group. The asterisk indicates significant differences between the abundances of spider morphospecies when in the presence or absence of the weaver ant following a GLMM. $p$-value $<.0001={ }^{* * *}$, $p$-value $<.05={ }^{*}$. Picture insert represents a female (top) and a male of Myrmarachne sp. spider sampled in presence of the weaver ant. Scale bar represents $1 \mathrm{~mm}$

morphologies and hunting strategies (web weavers, ambush hunters and active hunters) are therefore preserved and even reinforced. Co-occurrence of spiders and weaver ants in overlapping and/or adjacent trophic niches may thus extend and increase their predatory control over several pests, including Bactrocera flies which they prey upon (Kaspi, 2000; Picchi et al., 2015; Whitman et al., 1988). Further studies should investigate possible synergistic effects between spiders and weaver ants for the biological control of pests such as $B$. dorsalis fruit flies, with ants being more efficient at capturing Bactrocera at the egg or larval stage on the mango fruit (Vayssières et al., 2015), and spiders better regulating the winged adults on the foliage.

\section{ACKNOWLEDGEMENTS}

The authors would like to thank the mango orchard owners and keepers who kindly opened their fields to us, as well as Massamba
Diakhate from the Biopass laboratory in Dakar for his help and his translation skills. Claire Detrain is Research Director from the Belgian National Fund for Scientific Research. The travel to the fieldwork site in Dakar, Senegal, was made possible thanks to the financial support of the "Académie de Recherche et d'Enseignement Supérieur" (ARES) of the Wallonia-Brussels Belgian federation. An additional TROPIMUNDO funding made the stay on site possible and granted the possibility of the fieldwork.

\section{CONFLICT OF INTEREST}

The authors have no conflict of interest to declare in relation to this work.

\section{DATA AVAILABILITY STATEMENT}

The data that support the findings of this study are available from the corresponding author upon request. 


\section{ORCID}

Thibault Nève de Mévergnies (D) https://orcid. org/0000-0003-2608-7805

\section{REFERENCES}

Bates, D., Mächler, M., Bolker, B., \& Walker, S. (2015). Fitting linear mixed-effects models using Ime4. Journal of Statistical Software, 67. 1-48. https://doi.org/10.18637/jss.v067.i01

Cloudsley-Thompson, J. (1995). A review of the anti-predator devices of spiders. Bulletin of the British Arachnological Society, 10, 81-96.

Collart, A. (1941). Notes complémentaires sur Myrmarachne foenisex Simon, araignée myrmécomorphe du Congo belge. Bulletin Du Musée Royal D'histoire Naturelle De Belgique - Mededeelingen Van Het Koninklijk Natuurhistorisch Museum Van België, 17, 1-11.

Cushing, P. E. (2012). Spider-ant associations: An updated review of myrmecomorphy, myrmecophily, and myrmecophagy in spiders. Psyche: A Journal of Entomology, 2012, 1-23. https://doi. org/10.1155/2012/151989

de Bon, H., Huat, J., Parrot, L., Sinzogan, A., Martin, T., Malézieux, E., \& Vayssières, J. F. (2014). Pesticide risks from fruit and vegetable pest management by small farmers in sub-Saharan Africa. A review. Agronomy for Sustainable Development, 34, 723-736. https://doi. org/10.1007/s13593-014-0216-7

Dejean, A. (1990). Circadian rhythm of Oecophylla longinoda in relation to territoriality and predatory behaviour. Physiological Entomology, 15, 393-403. https://doi.org/10.1111/j.1365-3032.1990.tb00528.x

Diamé, L., Grechi, I., Rey, J.-Y., Sané, C. A. B., Diatta, P., Vayssières, J.-F., Yasmine, A., Bon, H. D., \& Diarra, K. (2015). Influence of Oecophylla longinoda Latreille, 1802 (Hymenoptera: Formicidae) on mango infestation by Bactrocera dorsalis (Hendel) (Diptera: Tephritidae) in relation to senegalese orchard design and management practices. African Entomology, 23, 294-305. https://doi. org/10.4001/003.023.0207

Diamé, L., Rey, J. Y., Vayssières, J. F., Grechi, I., Chailleux, A., \& Diarra, K. (2017). Ants: Major functional elements in fruit agro-ecosystems and biological control agents. Sustainability, 10, 1-18. https://doi. org $/ 10.3390 /$ su10010023

Edmunds, M. (1978). On the association between Myrmarachne spp. (Salticidae) and ants. Bulletin of the British Arachnological Society, 4, 149-160.

Grzywacz, D., Stevenson, P. C., Mushobozi, W. L., Belmain, S., \& Wilson, K. (2014). The use of indigenous ecological resources for pest control in Africa. Food Security, 6, 71-86. https://doi.org/10.1007/ s12571-013-0313-5

Harwood, J. D., Sunderland, K. D., \& Symondson, W. O. C. (2003). Weblocation by linyphiid spiders: Prey-specific aggregation and foraging strategies. Journal of Animal Ecology, 72, 745-756. https://doi. org/10.1046/j.1365-2656.2003.00746.x

Hölldobler, B. (1979). Territories of the African weaver ant (Oecophylla longinoda [Latreille]); A field study. Zeitschrift Für Tierpsychologie, 51, 201-213. https://doi.org/10.1111/j.1439-0310.1979.tb006 83.x

Hölldobler, B., \& Wilson, E. O. (1990). The Ants (p. 732). Springer-Verlag Berlin Heidelberg, Harvard University Press.

Hung, K. Y., Michailides, T. J., Millar, J. G., Wayadande, A., \& Gerry, A. C. (2015). House fly (Musca domestica L.) attraction to insect honeydew. PLoS One, 10, 1-14. https://doi.org/10.1371/journ al.pone. 0124746

Jocqué, R., \& Dippenaar-Schoeman, A. S. (2007). Spider families of the world. Royal Museum for Central Africa.

Johnson, J. B., \& Stafford, M. P. (1985). Adult Noctuidae feeding on aphid honeydew and a discussion of honeydew feeding by adult Lepidoptera. Journal of the Lepidopterists' Society, 39, 321-327.
Kaspi, R. (2000). Attraction of female Chiracanthium mildei (Araneae: Clubionidae) to olfactory cues from male mediterranean fruit flies Ceratitis capitata (Diptera: Tephritidae). BioControl, 45, 463-468. https://doi.org/10.1023/A:1026593004360

Kindt, R., \& Coe, R. (2005). Tree diversity analysis. A manual and software for common statistical methods for ecological and biodiversity studies, Nairobi, Kenya: World Agroforestry Centre. http://apps.worldagrof orestry.org/downloads/Publications/PDFS/b13695.pdf

Letourneau, D. K., Jedlicka, J. A., Bothwell, S. G., \& Moreno, C. R. (2009). Effects of natural enemy biodiversity on the suppression of arthropod herbivores in terrestrial ecosystems. Annual Review of Ecology, Evolution, and Systematics, 40, 573-592. https://doi.org/10.1146/ annurev.ecolsys.110308.120320

Marín, L., \& Perfecto, I. (2013). Spider diversity in coffee agroecosystems: The influence of agricultural intensification and aggressive ants. Environmental Entomology, 42, 204-213. https://doi.org/10.1603/ en11223

Michalko, R., \& Pekár, S. (2016). Different hunting strategies of generalist predators result in functional differences. Oecologia, 181, 11871197. https://doi.org/10.1007/s00442-016-3631-4

Migani, V., Ekesi, S., Merkel, K., \& Hoffmeister, T. (2017). At lunch with a killer: The effect of weaver ants on host-parasitoid interactions on mango. PLoS One, 12, 1-19. https://doi.org/10.1371/journ al.pone.0170101

Mody, K., \& Linsenmair, K. E. (2004). Plant-attracted ants affect arthropod community structure but not necessarily herbivory. Ecological Entomology, 29, 217-225. https://doi. org/10.1111/j.1365-2311.2004.0588.x

Nyffeler, M., \& Birkhofer, K. (2017). An estimated 400-800 million tons of prey are annually killed by the global spider community. The Science of Nature, 104. 1-12. https://doi.org/10.1007/s0011 4-017-1440-1

Nyffeler, M., Olson, E. J., \& Symondson, W. O. C. (2016). Plant-eating by spiders. The Journal of Arachnology, 44, 15-27. https://doi. org/10.1636/P15-45.1.

Oksanen, J., Blanchet, F. G., Friendly, M., Kindt, R., Legendre, P., McGlinn, D., Minchin, P. R., O'Hara, R. B., Solymos, P., \& Stevens, M. H. H. (2019). vegan: Community Ecology Package. $R$ package version 2.5-6. https://CRAN.R-project.org/package=vegan

Peng, R., \& Christian, K. (2013). Do weaver ants affect arthropod diversity and the natural-enemy-to-pest ratio in horticultural systems? Journal of Applied Entomology, 137, 711-720. https://doi. org/10.1111/jen.12058

Picchi, M. S., Entling, M. H., \& Petacchi, R. (2015). Effects of seminatural habitats on spiders in olive groves and their potential role against Bactrocera oleae (Rossi) (Diptera: Tephritidae). Agriculture, Ecosystems \& Environment, 222, 138-147. https://doi.org/10.1016/j. agee.2016.01.045

Pinkalski, C., Damgaard, C., Jensen, K. M. V., Gislum, R., Peng, R., \& Offenberg, J. (2015). Non-destructive biomass estimation of Oecophylla smaragdina colonies: A model species for the ecological impact of ants. Insect Conservation and Diversity, 8, 464-473. https://doi.org/10.1111/icad.12126

Porter, S. D., \& Savignano, D. A. (1990). Invasion of polygyne fire ants decimates native ants and disrupts arthropod community. Ecology, 71, 2095-2106. https://doi.org/10.2307/1938623

R Core Team (2020). R: A language and environment for statistical computing. R Foundation for Statistical Computing. https://www.R-proje ct.org/

Rajeswaran, J., Duraimurugan, P., \& Shanmugam, P. S. (2005). Role of spiders in agriculture and horticulture ecosystem. International Journal of Food Agriculture and Environment, 3, 147-152.

Riechert, S. E., \& Lockley, T. (1984). Spiders as biological control agents. Annual Review of Entomology, 29, 299-320. https://doi.org/10.1146/ annurev.en.29.010184.001503 
Rosenheim, J. A., Kaya, H. K., Ehler, L. E., Marois, J. J., \& Jaffee, B. A (1995). Intraguild predation among biological-control agents: Theory and evidence. Biological Control, 5, 303-335. https://doi. org/10.1006/bcon.1995.1038

Roughgarden, J. (1976). Resource partitioning among competing species-A coevolutionary approach. Theoretical Population Biology, 9, 388-424. https://doi.org/10.1016/0040-5809(76)90054-X

RStudio Team (2020). RStudio: Integrated development for R. RStudio, PBC, Boston, MA. http://www.rstudio.com/

Sanders, D., \& van Veen, F. J. F. (2011). Ecosystem engineering and predation: The multi-trophic impact of two ant species. Journal of Animal Ecology, 80, 569-576. https://doi. org/10.1111/j.1365-2656.2010.01796.x

Schmidt, M. H., Clough, Y., Schulz, W., Westphalen, A., \& Tscharntke, T. (2006). Capture efficiency and preservation attributes of different fluids in pitfall traps. Handbook of Environmental Chemistry, Volume 5: Water Pollution, 34, 159-162. https://doi.org/10.1636/T04-95.1

Stankowich, T. (2009). When predators become prey: Flight decisions in jumping spiders. Behavioral Ecology, 20, 318-327. https://doi. org/10.1093/beheco/arp004

Tanga, C. M., Ekesi, S., Govender, P., Nderitu, P. W., \& Mohamed, S. A. (2015). Antagonistic interactions between the African weaver ant Oecophylla longinoda and the parasitoid Anagyrus pseudococci potentially limits suppression of the invasive mealybug Rastrococcus iceryoides. Insects, 7, 1-17. https://doi.org/10.3390/insects701 0001

Thurman, J. H., Northfield, T. D., \& Snyder, W. E. (2019). Weaver ants provide ecosystem services to tropical tree crops. Frontiers in Ecology and Evolution, 7, 1-9. https://doi.org/10.3389/fevo.2019.00120

Tsuji, K., Hasyim, A., Nakamura, H., \& Nakamura, K. (2004). Asian weaver ants, Oecophylla smaradigma, and their repelling of pollinators. Ecological Research, 19, 669-673.

Vayssières, J. F., Offenberg, J., Sinzogan, A., Adandonon, A., Wargui, R. B., Anato, F. M., Houngbo, H. Y., Ouagoussounon, I., Diamé, L., Quilici, S., Rey, J.-Y., Georgen, G., De Meyer, M., \& Van Mele, P. (2016). The use of weaver ants in the management of fruit flies in Africa. In S. Ekesi S.A. Mohamed \& M. De Meyer (Eds.), Fruit fly research and development in Africa - Towards a sustainable management strategy to improve horticulture, (pp. 389-434). Switzerland: Springer. https:// doi.org/10.1007/978-3-319-43226-7

Vayssières, J.-F., Ouagoussounon, I., Adandonon, A., Sinzogan, A., Korie, S., Todjihoundé, R., Alassane, S., Wargui, R., Anato, F., \& Goergen, G. (2015). Seasonal pattern in food gathering of the weaver ant Oecophylla longinoda (Hymenoptera: Formicidae) in mango orchards in Benin. Biocontrol Science and Technology, 25, 1359-1387. https://doi.org/10.1080/09583157.2015.1048425
Vayssières, J.-F., Sinzogan, A., Adandonon, A., Rey, J.-Y., Dieng, E. O., Camara, K., Sangaré, M., Ouedraogo, S., Hala, N., Sidibé, A., Keita, Y., Gogovor, G., Korie, S., Coulibaly, O., Kikissagbé, C., Tossou, A., Billah, M., Biney, K., Nobime, O., ... Tamo, M. (2014). Annual population dynamics of mango fruit flies (Diptera: Tephritidae) in West Africa: Socio-economic aspects, host phenology and implications for management. Fruits, 69, 207-222. https://doi.org/10.1051/fruit s/2014011

Wanless, F. R. (1978). A revision of the spider genera Belippo and Myrmarachne (Araneae: Salticidae) in the Ethiopian region. Bulletin of the Natural History Museum. Zoology Series, 33, 1-139.

Way, M. J. (1954). Studies of the life history and ecology of the ant Oecophylla longinoda Latreille. Bulletin of Entomological Research, 45, 93-112. https://doi.org/10.1017/S0007485300026821

Way, M. J. (1963). Mutualism between ants and honeydew-producing homoptera. Annual Review of Entomology, 8, 307-344. https://doi. org/10.1146/annurev.en.08.010163.001515

Whitman, D. W., Orsak, L., \& Greene, E. (1988). Spider mimicry in fruit flies (Diptera: Tephritidae): Further experiments on the deterrence of jumping spiders (Araneae: Salticidae) by Zonosemata vittigera (Coquillett). Annals of the Entomological Society of America, 81, 532536. https://doi.org/10.1093/aesa/81.3.532

Wickham, H. (2016). ggplot2: Elegant graphics for data analysis. SpringerVerlag New York. https://ggplot2.tidyverse.org

Wise, D. H. (1993). Spiders in ecological webs. Cambridge University Press.

Wojtusiak, J., Godzińska, E. J., \& Dejean, A. (1995). Capture and retrieval of very large prey by workers of the African weaver ant, Oecophylla longinoda (Latreille 1802). Tropical Zoology, 8, 309-318. https://doi. org/10.1080/03946975.1995.10539287

Zhang, S., Koh, T. H., Seah, W. K., Lai, Y. H., Elgar, M. A., \& Li, D. (2012). A novel property of spider silk: Chemical defence against ants. Proceedings of the Royal Society B: Biological Sciences, 279, 18241830. https://doi.org/10.1098/rspb.2011.2193

How to cite this article: Nève de Mévergnies, T., Chailleux, A., \& Detrain, C. (2021). The African weaver ant has no negative impact on spiders in mango orchards of Senegal. African Journal of Ecology, 00, 1-8. https://doi.org/10.1111/ aje.12910 


\section{APPENDIX 1}

TABLE A1 Localisation and description of the sampled orchards

\begin{tabular}{llll}
\hline Orchard & Location & Latitude, Longitude & Crop diversity \\
\hline 1 & Keur Sega & $14^{\circ} 48^{\prime} 25.14^{\prime \prime} \mathrm{N}, 17^{\circ} 7^{\prime} 8.43^{\prime \prime} \mathrm{W}$ & Mango trees and citrus \\
\hline 2 & Keur Moussa & $14^{\circ} 46^{\prime} 24.35^{\prime \prime} \mathrm{N}, 17^{\circ} 6^{\prime} 31.00^{\prime \prime} \mathrm{W}$ & Mango trees and citrus \\
\hline 3 & Deni Biram Ndaw & $14^{\circ} 50^{\prime} 26.05^{\prime \prime} \mathrm{N}, 17^{\circ} 10^{\prime} 6,72^{\prime \prime} \mathrm{W}$ & Mango trees, citrus and vegetables \\
\hline 4 & Deni Biram Ndaw & $14^{\circ} 50^{\prime} 24.10^{\prime \prime} \mathrm{N}, 17^{\circ} 10^{\prime} 6.43^{\prime \prime} \mathrm{W}$ & Mango trees, citrus and vegetables \\
\hline 5 & Khaye & $14^{\circ} 46^{\prime} 30.02^{\prime \prime} \mathrm{N}, 17^{\circ} 5^{\prime} 10.84^{\prime \prime} \mathrm{W}$ & Mango trees, citrus and vegetables \\
\hline 6 & Sangalkam & $14^{\circ} 47^{\prime} 21.01^{\prime \prime} \mathrm{N}, 17^{\circ} 13^{\prime} 37.76^{\prime \prime} \mathrm{W}$ & Mango trees, citrus and vegetables \\
\hline 7 & Sangalkam & $14^{\circ} 47^{\prime} 26.80^{\prime \prime} \mathrm{N}, 17^{\circ} 13^{\prime} 40.63^{\prime \prime} \mathrm{W}$ & Mango trees, citrus and vegetables \\
\hline 8 & Khaye & $14^{\circ} 46^{\prime} 35.48^{\prime \prime} \mathrm{N}, 17^{\circ} 5^{\prime} 4.21^{\prime \prime} \mathrm{W}$ & Mango trees and citrus \\
\hline 9 & Bayakh & $14^{\circ} 50^{\prime} 35.35^{\prime \prime} \mathrm{N}, 17^{\circ} 7^{\prime} 10.77^{\prime \prime} \mathrm{W}$ & Mango trees \\
\hline 10 & Bambilor & $14^{\circ} 48^{\prime} 14.93^{\prime \prime} \mathrm{N}, 17^{\circ} 12^{\prime} 34.80^{\prime \prime} \mathrm{W}$ & Mango trees \\
\hline
\end{tabular}

\section{APPENDIX 2}

TABLE A2 Composition of the sampled spider families in terms of morphospecies and total abundance. "MS" is the total number of spider morphospecies, and $N$ is the total abundance for each sampled family

\begin{tabular}{|lrr|}
\hline Family & MS & N \\
\hline Araneidae & 19 & 133 \\
\hline Clubionidae & 5 & 95 \\
\hline Ctenidae & 3 & 16 \\
\hline Corinnidae & 4 & 12 \\
\hline Dictynidae & 2 & 5 \\
\hline Gnaphosidae & 14 & 86 \\
\hline Lycosidae & 13 & 70 \\
\hline Miturgidae & 2 & 4 \\
\hline Oxyopidae & 7 & 63 \\
\hline Palpimanidae & 2 & 3 \\
\hline Philodromidae & 2 & 12 \\
\hline Pholcidae & 1 & 1 \\
\hline Salticidae & 25 & 114 \\
\hline Scytodidae & 1 & 5 \\
\hline Therididae & 1 & 1 \\
\hline Thomisidae & 22 & 223 \\
\hline Uloboridae & 3 & 5 \\
\hline Unknown & 9 & 13 \\
\hline
\end{tabular}

